\title{
THE ECONOMICS OF ECOSYSTEMS AND BIODIVERSITY, REDD + AND CLIMATE CHANGE IN MANGROVE ECOSYSTEMS OF SOUTHEAST ASIA
}

\section{Filiberto Pollisco}

Policy and Program Development Specialist

ASEAN Centre for Biodiversity

Los Banos, Laguna, Philippines

\section{Dicky Simorangkir}

International Senior Adviser

Biodiversity \& Climate Change Project

GIZ-ACB, Los Banos, Laguna, Philippines

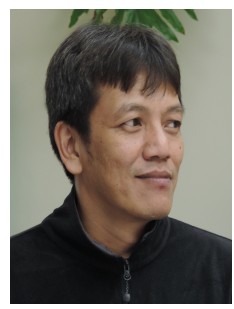

Mangroves are trees and shrubs that grow in saline coastal habitats. They occupy large stretches of the sub-tropical and tropical coastlines around the world. They not only provide valuable goods such as timber, fish and medicinal plants but also vital ecological services, such as prevention of coastal erosion. They also help buffer coastal communities from storms and floods. During the ASEAN Conference on Biodiversity held in Singapore in 2009, Ellison reported that mangrove forests in South East Asia are among the highest biodiversity resources in the world, occupying an area of $60.9 \times 10^{2} \mathrm{~km}^{2}$. Unfortunately, the region also has the highest rates of mangrove loss in the world, losing $628 \mathrm{~km}^{2}$ per year in two decades. In many parts of the world, where mangrove forests have been cleared, there are now problems of erosion and siltation, and loss of life and property have occurred due to destructive hurricanes, storms and tsunamis.

The complex relationship between climate change and mangrove ecosystems can be seen from two different angles. On the one hand, mangrove ecosystems have a critical function in combating climate change; on the other hand, they are affected by climate change. The values of ecosystems vary according to local biophysical and ecological circumstances and the social, economic and cultural context. Intangible values, which may be reflected in society's willingness to pay to conserve particular species or landscapes, or to protect common resources, must be considered alongside more tangible values such as food or timber to provide a complete economic picture. This has important implications for mangrove conservation strategies and suggests that the preservation of contiguous areas is preferable to patches that are spatially dispersed.

\section{Introduction}

Have you ever seen the mangrove forests at the mouth of Muara Angke River in North Jakarta? Here you can see ugly-looking trees and other vegetation growing in an area littered with garbage and swamped with stinky water full of all kinds of solid and liquid wastes. It is hard to imagine that the vegetation, called mangroves, play a critical in ensuring livelihoods and fighting against climate change.

For many decades, mangroves were not taken seriously as an important ecosystem. They have been forgotten or ignored in all debates about illegal logging, land use changes, and global warming. Only in recent years have mangroves received more attention as people began to realise their significance to the economy and environment.

Mangroves are trees and shrubs that grow in saline coastal habitats. They occupy large stretches of the subtropical and tropical coastlines around the world. They not only provide valuable goods such as timber, fish and medicinal plants but also vital ecological services, such as prevention of coastal erosion. They also help buffer coastal communities from storms and floods. According to some reports, the annual economic value of products and services that mangroves provide is between US\$200,000 and US\$900,000 per hectare. ${ }^{1}$

\footnotetext{
'SC Wells, C Ravilous and E Corcoran, 'In the frontline: Shoreline protection and other ecosystem services from man-
} groves and coral reefs' (United Nations Environment Programme World Conservation Monitoring Centre, 2006) 33. 


\section{Status of ASEAN Mangroves}

Ellison, in 2009 during the ASEAN Conference on Biodiversity held in Singapore, reported that mangrove forests in South East Asia are among the highest biodiversity resources in the world, occupying an area of $60.9 \times 10^{2} \mathrm{~km}^{2} .^{2}$ The Indo-Malayan Philippine archipelago has 36 to 47 of the 70 known mangrove species occurring in the region. Scientists have identified that Southern New Guinea, including West Papua, is the location of the center of the Indo-Malayan mangrove biodiversity. Unfortnately, the region, also has the highest rates of mangrove loss in the world, losing $628 \mathrm{~km}^{2}$ per year in two decades. ${ }^{3}$

Aquaculture development in mangrove intertidal areas causes 50 to 80 per cent of mangrove loss in Southeast Asia. Peripheral damage to coastal values from this conversion include discharge of nutrient-rich waters that causes eutrophication, associated depletion of natural stocks of fish and crustaceans, and accumulation of toxins in aquaculture ponds that cause them to become unusable after only a few years leading to abandonment and encouraging the conversion to aquaculture of other mangrove areas elsewhere. ${ }^{4}$ Many scientists identified the leading causes of mangrove loss and degradation as due to human impacts, including direct clearing for coastal development, aquaculture, population encroachment, overexploitation for fuelwood and timber production. These activities have degraded a further 26 per cent of Southeast Asian mangrove forest. ${ }^{5}$

There are three species of mangroves of special concern in the ASEAN region: Bruguiera hainesii, Sonneratia griffithii and Camptostemon philippinense. These are listed under the IUCN Red List of Endangered Species, categorised as 'critically endangered'. The first is a very rare species identified in a few locations in Indonesia, Malaysia, Thailand, and Myanmar. The second can be found in parts of India and Southeast Asia where the highest mangrove forest loss has occured over the past 60 years. The third is estimated to have 1200 or fewer individuals remaining.

The medium-sized tree Heritiera globosa is an associated species of the mangrove ecosystem and is categorised as 'endangered'. It has a restricted distribution, estimated to occur in an area of less than $5,000 \mathrm{sq} \mathrm{km}$ in Western Borneo and Indonesia where it is patchily distributed, especially in riparian habitats where clearing occurs for timber and oil palm plantations.

\section{Climate change and the mangrove ecosystem}

The complex relationship between climate change and mangrove ecosystems can be seen from two different angles. On the one hand, mangrove ecosystems have a critical function in combating climate change, on the other hand, they are affected by climate change.

\section{Mangrove ecosystem: The first line of defense in combating climate change}

Mangroves are one of nature's best ways for combating global warming. They quickly develop root biomass. Almost half of the biomass of mangrove forests is below ground. ${ }^{6}$ These root systems and the slowlydecomposing thick organic layer in the soil enable mangroves to store carbon up to four times more effectively than tropical rainforests. Some studies estimate that mangroves are able to sequester up to three to four tonnes of carbon per hectare per year, which is approximately equivalent to the amount of carbon two to three motor vehicles release into the atmosphere each year. ${ }^{7}$ In addition to its carbon storage function, mangroves are a first defense lines against anticipated sea level rise as they provide immediate protection to coastal communities from storm surges and floods. ${ }^{8}$

With the clearing of mangroves, we not only lose their important carbon sequestration potential, but also release polluting gases from the disturbed mangrove substrate. The ten per cent of the upper layer of mangrove sediments is composed of carbon, and each hectare of mangrove sediment is estimated to

2 J C Ellison, 'Climate Change Impacts on, and Vulnerability and Adaptation of Mangrove Ecosystems' (Paper presented at the ASEAN Conference on Biodiversity, Singapore, October 2009).

3 Ibid.

${ }^{4}$ Ibid.

5 J E Ong and G W Khoon, 'Carbon Fixation in Mangrove Ecosystem and Carbon Credits' (Theme B from the East Asia Seas Congress: Essential Cross-Sectoral Processes and Approaches to Achieving Sustainable Development, 2003).

${ }^{6}$ Deborah Zabarenko, 'Mangroves Excel at Storing Carbon', ABC Science: News in Science (online) 4 April 2011 </science/news/?site=science). www.abc.net.au/science/articles/2011/04/04/3181798.htm>.

Ibid.

Wells et al, above $\mathrm{n} 1$. 
contain some 700 tonnes of carbon per metre depth. Digging up two metres of soil to create shrimp ponds, for example, could result in the potential oxidation of 1,400 tonnes of carbon per hectare per year. Estimates are that the deforestration of mangroves will release as much as ten per cent of all emissions worldwide even though mangroves account for just 0.7 per cent of the tropical forest area. ${ }^{9}$

Estimates are that, fifty years ago, mangroves covered 32 million hectares. The area covered by mangroves today is less than half number and destruction continues at an alarming rate with loss of mangroves at around 150,000 ha per year globally. This means there is a loss of 225,000 tons of carbon sequestration potential each year and a release of approximately 11 million tons of carbon from disturbed mangrove soils each year. ${ }^{10}$

The loss of mangroves damages local economies and the livelihood of coastal communities. It also leaves nearly half of the world's population living in cities and settlements along the coasts 'less protected' from the consequences of global warming, such as sea level rise and storm surges. In many parts of the world, where mangrove forests have been cleared, there are now problems of erosion and siltation, and loss of life and property have occurred due to destructive hurricanes, storms and tsunamis. It is expected that millions of coastal residents will have to be evacuated within the next 50 years as sea level continue to rise. ${ }^{11}$

\section{Impact of climate change on mangrove ecosystems}

There are three levels at which climate change affects mangrove ecosystem. The first is at the tissue/cellular level where the physiology of the mangrove plant is affected. Changing environmental conditions, such as rising temperatures, increased atmospheric carbon dioxide, changes in ultra-violet radiation, and precipitation (rainfall) changes, affect the growth and survival of the mangrove plant. Rising temperature combined with low humidity and rainfall influences photosynthetic rates, thereby reducing the primary productivity of the mangrove plant; increased atmospheric $\mathrm{CO}_{2}$ influences the respiration physiology and influences plant growth and development and its primary productivity (that is, its plant mass); increased ultra violet radiation changes damage proteins and nucleotides and, therefore, plant tissues; and more precipitation or rainfall would disrupt the salinity patterns of the ocean thus reducing plant growth. Effects at specific site would depend on its condition and other factors such as human impact. $^{12}$

The second level is at the ecosystem-wide effect. Increased rainfall and sea level rise both affect the growth of the mangrove plants. According to Ellison, ${ }^{13}$ increased rainfall would reduce salinity and the extent of mangrove zones can be expected to increase particularly on the landward side where colonisation of unvegetated areas would occur. Sea level rise would effect the seaward side of mangroves as well by 'drowning' mangroves. Ellison stressed that the mangrove ecosystem is "one of the most vulnerable ecosystems to be strongly affected by sea level rise caused by climate change". ${ }^{14}$

The third level is the region-wide effect, in which upper latitudes would have increased (warmer) temperatures, paving the way for mangroves to move north and south. Mangrove distribution are also limited by temperature, not colonising areas with isotherm levels greater than $16^{0} \mathrm{C} .{ }^{15} \mathrm{~A}$ rise in this temperature would pave the way for mangroves to occupy latitudes where they were not previously present.

\section{The economics of ecosystems and biodiversity and REDD+}

The REDD+ mechanism, reflecting climate change concerns, focuses on the carbon stock of the target ecosystem. It aims to prevent carbon being released into the atmosphere, thereby exacerbating global warming. Putting monetary value on these carbon stocks and making these funds available to resource managers can finance resource management activities that address climate change. The biomass of mangrove plants are underground in the root system. Putting value only on the above-ground standing

\footnotetext{
Zabarenko, above n 6.

${ }^{10}$ D Simorangkir, 'Mangrove and Climate Change' (unpublished, 2012).

11 Ibid.

${ }^{12}$ Ellison, above $\mathrm{n} 2$

13 Ibid.

14 J C Ellison, 'Possible Impacts of Predicted Sea Level Rise on South Pacific Mangroves' in J Noye and M Grzechnik (eds), Sea-level Changes and their Effects (World Scientific Publishing, 2011) 49.

${ }^{15}$ Ellison, above $\mathrm{n} 2$.
} 
mangrove trees under-values the carbon stock of the mangrove ecosystem. It also ignores the fact that mangroves are high in biodiversity. Linking this biodiversity with the REDD+ mechanism would increase the economic value of the ecosystem. It would further recognise that there are benefits other than the monetary value of carbon and its sequestration.

In 2007, environment ministers from the governments of the G8+5 countries, meeting in Potsdam, Germany, agreed to 'initiate the process of analyzing the global economic benefit of biological diversity, the costs of the loss of biodiversity and the failure to take protective measures versus the costs of effective conservation'. ${ }^{16}$ The Economics of Ecosystems and Biodiversity (TEEB) study, which emerged from that decision, has delivered a series of reports addressing the needs of major user groups, national and local decision makers, business and the wider public. ${ }^{17}$ The aim of TEEB is to show how economic concepts and tools can help equip society with the means to incorporate the values of nature into decision making at all levels. The invisibility of biodiversity values has often encouraged inefficient use or even destruction of the natural capital that is the foundation of our economies. Taking biodiversity values into account would encourage the conservation and sustainable management of these resources.

Another aim of TEEB is to provide a bridge between the multi-disciplinary science of biodiversity and international and national policy as well as local government and business practices. The scope of TEEB is intentionally broad and aims inspire and invite others to deepen its findings and develop more contextspecific recommendations. Ideally, TEEB should act as a catalyst to help accelerate the development of a new economy - one in which the values of natural capital, and the ecosystem services which this capital supplies, are fully reflected in the mainstream of public and private decision-making. ${ }^{18}$

The bottom-line objective of TEEB and REDD+ is sustainable resource management. The strategies of both is to put a monetary value on the resource: REDD+ values the carbon stock of the mangrove and its biodiversity; TEEB values the goods and services which the mangrove ecosystem provides arising from its biodiversity. Under TEEB, carbon sequestration is just one service the mangrove ecosystem provides.

Applying economic thinking to the use of biodiversity and ecosystem services can help clarify two critical points: why prosperity and poverty reduction depend on maintaining the flow of benefits from ecosystems: and why successful environmental protection needs to be grounded in sound economics, including explicit recognition, efficient allocation, and fair distribution of the costs and benefits of conservation and sustainable use of natural resources. ${ }^{19}$

Unfortunately, the negative impacts of mangrove loss are often underestimated or ignored in decision making and development planning processes. In 1997, the UNESCAP estimated the eco-system services were worth USD\$16-54 trillion annually. However, the value of ecosystem services lost annually word wide was between UD\$2-5 trillion. $^{20}$

The UN-REDD+ program recognises that there are co-benefits in the REDD+ mechanism other than carbon sequestration. The ecosystem provides goods and services that are the co-benefits of the mangroves. The Millennium Ecosystem Assessment defines ecosystem services as the benefits people obtain from the ecosystem. ${ }^{21}$ There are four broad categories of ecosystem services:

1. Support services. These are services that are the regular function of the ecosystem, which are energy transfer, nutrient cycling and soil formation. In the case of the mangrove ecosystem, organisms such as fiddler crabs and other crustaceans break down organic matter to their elemental form which plants can take up for their nourishment to sustain the ecosystem. Mangroves also serve as catchment of sediments and build up soil for other mangrove-associated plants to come in and further enrich the ecosystem.

2. Provisioning services. These give benefits to the communities, not only human but also biological. The mangrove ecosystem provides edible plants as food, tannin for leather making, wood for shelter

\footnotetext{
${ }^{16}$ TEEB, The Economics of Ecosystems and Biodiversity: Mainstreaming the Economics of Nature: A synthesis of the approach, conclusions and recommendations of TEEB. (United Nations Environment Programme, 2010). ('TEEB synthesis report 2010').

${ }^{17}$ Ibid.

${ }^{18}$ Ibid.

19 Ibid.

${ }^{20}$ UNESCAP, 'Payments for ecosystem services: A guide for policy-makers' (Greening of Economic Growth Series, 2009) 7.

${ }^{21}$ United Nations, Millenium Ecosystems Assessment, Ecosystems and Human Well-Being: Synthesis Report (Island Press, 2005).
} 
and charcoal, and fiber for clothing and ropes. The mangrove ecosystem serves as nursery for juvenile fish and re-stocks the fish population of nearby coral ecosystems and the seas, for harvest in the future.

3. Regulating services. The mangrove ecosystem regulates the micro-climate of the area in which they are found. Instead of having high temperature from exposure to bare ground and water, the presence of mangroves provide shade, thereby cooling the immediate atmosphere and area around them. They also regulate the flooding that occurs during high rainfall in the upper elevations and the force of the waves during high winds and typhoons. By trapping the sediments from surface run-offs, they purify the water that goes into the sea.

4. Cultural services. In some cultural communities, the mangrove ecosystem serves as spiritual inspiration. In most cases, mangroves are utilised for recreation, education, and for aesthetic purposes.

\section{ASEAN TEEB scoping study: Case study on mangroves}

A low-carbon growth strategy (green growth) highlights the need for wider accounting and realistic valuation of the natural resources and ecosystem services that contribute to human well-being while simultaneously addressing climate change issues. ${ }^{22}$ An ASEAN study on The Economics of Ecosystems and Biodiversity is a significant next step for mainstreaming green growth in the development processes of the region. Using the UNEP TEEB study as the foundation, the study builds up evidence and frameworks for policy makers and technical officers on the proper valuation of ecosystems services as a measure for adapting to climate change impacts.

The objective of the ASEAN TEEB scoping study, conducted by the ASEAN Centre for Biodiversity (ACB), is to pursue the mainstreaming of the economics of ecosystems and biodiversity by conducting an assessment and valuation of key ecosystems in Southeast Asia, and assisting ASEAN member states to develop green growth economies. The mangrove ecosystem is one of the case studies for research.

This case study examined the value of ecosystem services provided by mangroves. It presents a metaanalysis of the economic valuation literature and applies the estimated value function to assess the value of mangroves in the ASEAN countries. We construct a database containing 130 value estimates, largely for mangroves in Southeast Asia. Values are standardised to US\$ per hectare per year in 2007 prices. The values of mangrove ecosystem services are highly variable across study sites due to, among other factors, the biophysical characteristics of the site and the socio-economic characteristics of the beneficiaries of ecosystem services. The study includes explanatory variables in the meta-analysis to account for these influences on estimated mangrove values. It uses a geographic information system (GIS) to quantify potentially important spatial variables, including the abundance of mangroves, the population of beneficiaries, and the density of roads in the vicinity of each study site. The meta-analytic value function is used to estimate the change in value of mangrove ecosystem services in Southeast Asia under a baseline scenario of mangrove loss for the period 2000-2050. The baseline scenario is derived from land use changes described by the IMAGE-GLOBIO model. ${ }^{23}$

The estimated foregone annual benefits by 2050 for the ASEAN region as whole are US\$2.2 billion (95\% prediction interval US\$ 1.6-2.8 billion). At a country level, the annual value of foregone mangrove ecosystem services by 2050 follows the pattern of loss of area, with Indonesia expected to suffer the highest losses: US\$1.7 billion per year (95\% prediction interval US\$1.2-2.2 billion). Malaysia is estimated to suffer the second highest losses in mangrove ecosystem service values: US\$279 million per year $(95 \%$ prediction interval of US\$ $228-330$ million). ${ }^{24}$

The values of biological resources and ecossystem services vary according to local biophysical and ecological circumstances and the social, economic and cultural context. Intangible values, which may be reflected in society's willingness to pay to conserve particular species or landscapes, or to protect common resources, must be considered alongside more tangible values such as food or timber to provide a complete

\footnotetext{
${ }^{22}$ ACB TEEB Scoping Study Report. 2012. Unpublished.

${ }^{23}$ Ibid.

${ }^{24}$ Ibid.
} 
economic picture. Valuation is not as a panacea but a tool to help recalibrate the faulty economic compass that has led to decisions that are prejudicial to both current well-being and that of future generations. ${ }^{25}$

\section{Future directions for research}

The inclusion of spatial variables to describe the context of individual mangrove patches is important in accounting for variation in ecosystem service values. There is evidence that mangrove areas are complements; that is, that the value of individual mangroves are enhanced when there is a larger extent of other mangrove patches in the surrounding area. This has important implications for mangrove conservation strategies and suggests that the preservation of contiguous areas is preferable to patches that are spatially dispersed. This finding is in contrast to the results of similar meta-analyses for freshwater wetlands, ${ }^{26}$ which have shown wetland ecosystems to be substitutes.

The fragmentation of mangroves and their surroundings by road infrastructure has a negative effect on the value of mangrove ecosystem services. Increasing the accessibility of mangrove areas appears to degrade the services they provide. This might particularly be the case for the coastal protection and fisheries habitat and nursery services, which are off-site services that do not require access to the mangrove itself. Mangrove conservation efforts should, therefore, aim to mitigate the impacts of fragmentation by transport infrastructure.

Regarding future research directions, the inclusion of other spatially defined context variables in metaanalyses of ecosystem service values offers a potentially important avenue to further account for variation in values. There is also a need for collaborative research that combines mangrove ecology and economics to jointly model the provision and value of ecosystem services from mangroves. The value transfer analysis conducted in this case study modeled the variation in the economic value of ecosystem services but made the assumption that the provision of services is a constant across all mangrove sites (the value of this constant is informed by the level of service provision observed at the study sites reviewed in the metaanalysis).

To a limited extent, spatial variation and non-linearity in ecosystem service provision are implicitly modeled in the meta-analytic value function through the inclusion of the mangrove area, abundance, and road density variables. Explicit ecological modeling of the potential non-linearities in the provision of ecosystem services would, however, be preferable. ${ }^{27}$ The value transfer analysis should therefore be revisited when (modeled) data on the provision of services from mangroves becomes available. Similarly, the estimation of changes in the stock of mangroves over time could be greatly improved by explicitly modeling the specific threats that face this biome, including sea level rise.

\footnotetext{
${ }^{25}$ TEEB, above $\mathrm{n} 10$.

${ }^{26}$ See, eg, L M Brander, R Brouwer and A Wagtendonk, 'Economic valuation of regulating services provided by wetlands in agricultural landscapes: a meta-analysis' (Paper presented at the OECD sponsored symposium on 'Bringing Together Science and Policy to Protect and Enhance Wetland Ecosystem Services in Agricultural Landscapes', Rotorua, New Zealand, 2011).

${ }^{27}$ TEEB, above n 10, citing Barbier et al, 2008; and Koch et al, 2009.
} 